\title{
Review \\ Gold Derivatives Development as Prospective Anticancer Drugs for Breast Cancer Treatment
}

\author{
Ileana Ielo $^{1} \mathbb{D}$, Domenico Iacopetta ${ }^{2} \mathbb{D}$, Carmela Saturnino ${ }^{3} \mathbb{D}$, Pasquale Longo $^{4}$, Maurilio Galletta ${ }^{5}$, \\ Dario Drommi $^{5}$ (D) Giuseppe Rosace ${ }^{6, *(D)}$, Maria Stefania Sinicropi ${ }^{2, *(D)}$ and Maria Rosaria Plutino ${ }^{1, *(D)}$
}

1 Institute for the Study of Nanostructured Materials, ISMN-CNR, Palermo, c/o Department of ChiBioFarAm, University of Messina, Viale F. Stagno d'Alcontres 31, Vill. S. Agata, 98166 Messina, Italy; ileana.ielo@ismn.cnr.it

2 Department of Pharmacy, Health and Nutritional Sciences, University of Calabria, Via Pietro Bucci, 87036 Arcavacata di Rende, Italy; domenico.iacopetta@unical.it

3 Department of Science, University of Basilicata, Viale dell'Ateneo Lucano 10, 85100 Potenza, Italy; carmela.saturnino@unibas.it

4 Department of Chemistry and Biology, University of Salerno, 84084 Fisciano, Italy; plongo@unisa.it

5 Department of ChiBioFarAm, University of Messina, Viale F. Stagno d'Alcontres 31, Vill. S. Agata, 98166 Messina, Italy; mgalletta@unime.it (M.G.); ddrommi@unime.it (D.D.)

6 Department of Engineering and Applied Sciences, University of Bergamo, Viale Marconi 5, 24044 Dalmine, Italy

* Correspondence: giuseppe.rosace@unibg.it (G.R.); s.sinicropi@unical.it (M.S.S.); mariarosaria.plutino@cnr.it (M.R.P.); Tel.: +39-03-5205-2021 (G.R.); +39-09-8449-3200 (M.S.S.); +39-09-0676-5713 (M.R.P.)

check for updates

Citation: Ielo, I.; Iacopetta, D.; Saturnino, C.; Longo, P.; Galletta, M.; Drommi, D.; Rosace, G.; Sinicropi, M.S.; Plutino, M.R. Gold Derivatives Development as Prospective Anticancer Drugs for Breast Cancer Treatment. Appl. Sci. 2021, 11, 2089. https://doi.org/10.3390/app11052089

Academic Editors: Giuliana Muzio and Francesca Silvagno

Received: 30 December 2020

Accepted: 20 February 2021

Published: 26 February 2021

Publisher's Note: MDPI stays neutral with regard to jurisdictional claims in published maps and institutional affiliations.

Copyright: (c) 2021 by the authors. Licensee MDPI, Basel, Switzerland. This article is an open access article distributed under the terms and conditions of the Creative Commons Attribution (CC BY) license (https:/ / creativecommons.org/licenses/by/ $4.0 /)$.

\begin{abstract}
Commonly used anticancer drugs are cisplatin and other platinum-based drugs. However the use of these drugs in chemotherapy causes numerous side effects and the onset of frequent drug resistance phenomena. This review summarizes the most recent results on the gold derivatives used for their significant inhibitory effects on the in vitro proliferation of breast cancer cell models and for the consequences deriving from morphological changes in the same cells. In particular, the study discusses the antitumor activity of gold nanoparticles, gold (I) and (III) compounds, gold complexes and carbene-based gold complexes, compared with cisplatin. The results of screening studies of cytotoxicity and antitumor activity for the gold derivatives show that the death of cancer cells can occur intrinsically by apoptosis. Recent research has shown that gold (III) compounds with square planar geometries, such as that of cisplatin, can intercalate the DNA and provide novel anticancer agents. The gold derivatives described can make an important contribution to expanding the knowledge of medicinal bioorganometallic chemistry and broadening the range of anticancer agents available, offering improved characteristics, such as increased activity and/or selectivity, and paving the way for further discoveries and applications.
\end{abstract}

Keywords: gold derivatives; cancer treatment; breast cancer; cytotoxicity; antitumor activity

\section{Introduction}

Approximately 9 million people around the world fall ill and die from cancer diseases every year, many of who do not receive adequate treatment due to the high cost. It is esteemed that the incidence of cancer will double by 2035 [1]. In particular, breast cancer is the most frequent type diagnosed, about $25 \%$ of all cancers [2,3]. The anticancer therapy currently in use consists of three main approaches: surgical removal of the tumor mass, chemotherapy and radiotherapy. Unfortunately, several types of metastatic tumors have been found to be chemoresistant [4]. The most common form of breast cancer, which makes up $60 \%$ of all diagnoses, is hormone receptor (HR) positive and human epidermal growth factor receptor 2 (HER2) negative [5]. Several studies have shown that HR positive patients have a better response to hormone therapy. However, the lack of HER2 
proteins causes a disposal of drugs specially designed to target these proteins as therapeutic options. The retinoblastoma $(\mathrm{Rb})$ protein, a tumor suppressor, regulates RNA transcription during the G1 cell growth phase to stop the proliferation of malignant cells [6]. Cyclin D1 proteins bind to cyclin-dependent kinase (CDK) enzymes 4 and 6 thereby inhibiting the regulatory function of the $\mathrm{Rb}$ protein. The National Comprehensive Cancer Network (NCCN) recognized CDK 4/6 inhibitors are palbociclib, abemaciclib and ribociclib in combination with aromatase inhibitors. Combination therapy provides treatment for HR positive/HER2 negative advanced or metastatic breast cancer by lowering estrogen levels to inhibit cell growth and cyclin-dependent kinase to block malignant cell division and proliferation $[7,8]$. Abemaciclib and ribociclib showed a relative reduction in the risk of death of 25-30\% [9]. By combining an aromatase inhibitor with palbociclib, progression free survival (PFS) is increased by 10 months, compared with hormone monotherapy [10]. Likewise, adding palbociclib to fulvestrant resulted in a double increase in PFS compared to those taking fulvestrant alone [11]. There is currently limited evidence to support the use of CDK 4/6 inhibitors as monotherapy. Increased data on the safety and tolerability of CDK 4/6 inhibitors in patients may help clinicians in the selection of initial therapy for patients with HR positive/HER2 negative breast cancer [12]. Platinum-based anticancer drugs such as cisplatin, carboplatin and oxaliplatin have been widely employed in the treatment of several types of cancer, such as lung, colorectal, ovarian and breast cancers [13]. However, the efficacy and, therefore, the use of such platinum-based drugs have decreased due to the high risk of serious toxicity, such as neurotoxicity [14,15]. Major advances have recently been made in drug delivery systems, due to miniaturization technologies that have improved the performance of existing drugs to provide new, more effective therapies [16]. The use of biomolecules such as peptides, nucleic acids and others reduced the amount of drug required by improving its targeted action [17]. The reduction in size at the nanometer level $(<100 \mathrm{~nm})$ has led to dramatic improvements in the way drugs are delivered [18]. All particles $<100 \mathrm{~nm}$ in size could be formed via nanocrystals, drug-polymer complexation or using nanoscale shells that could trap drugs [19]. The fine size of nanoparticles or metal complexes allows for a loading of small molecules, peptides, proteins and nucleic acids that escape immunological detection unlike larger particles, which are easily excluded from the body. Recently, innovative research has developed towards metal-based anticancer drugs, such as gold derivatives, with the aim of improving the effectiveness, expanding the activity field and, above all, reducing the general toxicity $[20,21]$. The pharmacological activity of gold compounds has been tested since ancient times; these compounds have been used in a series of treatments, including that for the rheumatoid arthritis and as an antibacterial and antitumor. Different studies have shown that gold derivatives act differently from platinum anticancer drugs, since their primary target is the proteasome; in this regards future approaches will bring to the development gold complexes selective for specific cancer cells and tumor targets in order to increase their effectiveness and better control of undesired side effects [22,23]. The purpose of this review is to summarize the state of the art of the antitumor activity of gold compounds, complexes and nanoconjugates, providing a brief overview of their use against breast cancer. In particular, the following aspects will be treated:

1. Drug delivery systems;

2. Gold nanosystems;

3. Gold complexes.

The antiproliferative activity of these systems has been studied in several human breast cancer cell lines. In vitro and ex vivo experiments have shown that this class of compounds shows significant antiproliferative activity against ovarian, prostate, lung and particularly breast cancers [24]. 


\section{Drug Delivery Systems}

Conventional cancer treatments, such as chemotherapy and radiotherapy, act in biological systems in a non-specific way, affecting both malignant and healthy cells. This affects the optimal therapeutic and implementation of gold derivatives.

Targeted delivery through gold derivatives can take place through two types: passive and active effect, reducing unwanted effects and the development of drug resistance [25]. Passive targeting allows the accumulation of a drug or drug transport system within a specific site due to the variation of physicochemical or pharmacological factors. This type of method exploits the size of the nanoparticles and the properties of the tumor vascular system, effectively improving the bioavailability and efficacy of the drug. The vascularity of the tumor is very different from normal tissue, in fact the blood vessels of the tumor tissues, unlike those in normal tissues, have spaces between the adjacent endothelial cells up to $600-800 \mathrm{~nm}$. These pathophysiological features of tumor vessels induce the Enhanced permeability and retention EPR (Enhanced Permeability and Retention) effect, which allows macromolecules, including nanoparticles, to extravasate through these extravascular spaces and accumulate within tumor tissues [26]. The accumulation of tumor drugs is ten times greater when the drug is administered from a nanoparticle rather than as a free drug. Another contributor to passive targeting is the unique microenvironment that surrounds cancer cells, which is different from that of normal cells. Fast-growing hyperproliferative cancer cells use glycolysis for extra energy, resulting in an acidic environment. The $\mathrm{pH}-$ sensitive liposomes are designed to be stable at a physiological $\mathrm{pH}$ but degraded to release the active drug into target tissues where the $\mathrm{pH}$ is lower, such as in the acidic environment of cancer cells [27]. Active targeting involves the attachment of a fraction, such as a monoclonal antibody or a ligand, to deliver a drug to pathological sites or to cross biological barriers based on molecular recognition processes [28-30]. When designing the synthesis of nanoparticles, it is necessary to consider some factors: for example, the antigen or receptor should be expressed exclusively and homogeneously on tumor cells and not expressed on healthy ones. The internalization of conjugates occurs through receptor-mediated endocytosis. Indeed, when a conjugate binds to its receptor on the cell surface, the plasma membrane envelops the receptor and ligand complex to form an endosome, this is transferred to target organelles.

When the $\mathrm{pH}$ value inside the endosome becomes acidic and lysozymes are activated, the drug is released from the conjugate and enters the cytoplasm. The receptor released by the conjugate returns to the cell membrane to begin a second transport cycle by binding with new conjugates. Ligands targeting cell surface receptors can be natural substances that have the advantages of a molar mass and lower immunogenicity than antibodies. Molecular targeted therapy is a potential solution to overcome these challenges, it can be achieved through smart design (Figure 1). Both methods allow increasing the concentration of the anticancer drug directly inside the tumor cell, causing the decrease of toxicity for healthy cells [30]. Gold derivatives (gold compounds, complexes and nanoparticles) can be conjugated to a wide range of biologically active organic molecules, designed to cross the blood-brain barrier, interact with specific receptors entering the cell through an alternative path. In particular, passive targeting of gold nanoparticles is based on the effect of enhanced permeability and retention (EPR) and tumor angiogenesis, while active targeting is based on direct binding from the ligand to receptors expressed by tumor cells [26]. Antitumor agents can be released as a function of $\mathrm{pH}$ or temperature [31,32]. 
Passive targeting

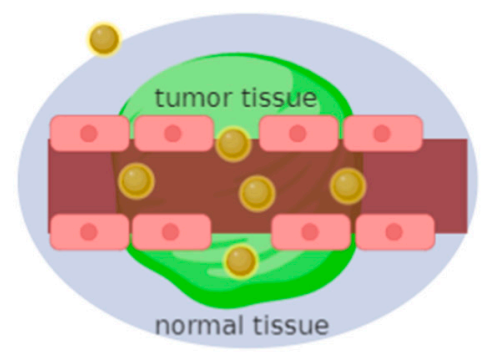

Active targeting

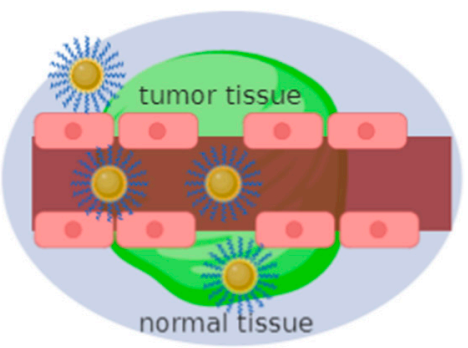

Figure 1. Schematic illustration of targeted strategies for cancer therapy by functional Gold Nanoparticles (Au-NPs, NPs = NanoParticles). Malignant tissue is distributed unevenly concerning healthy cells, hence the gold nanoparticles that cross the empty spaces due to the increase in permeability and the retention effect of passive drug release. This figure also illustrates active targeting with direct binding of gold nanoparticles to receptors with specific ligands.

\section{Gold Nanosystems}

Medical research on gold nanoparticles has been directed towards the study of drug delivery systems, chemotherapeutic agents, detection and diagnostics [33,34]. Gold nanosystems turned out to be attractive due to their unique properties, mainly dependent on their size and shape [35]. The resulting physical properties of nanoparticles strongly depend on the particle size, density, nature of the protective organic shell and their shape [36]. The quantum size effect occurs when the de Broglie wavelength of the valence electrons has the same dimensional order as the particle itself. Thus, the particles electronically behave like zero-dimensional quantum boxes. Therefore, the electrons are free to move inside these metal boxes with a collective oscillation frequency characteristic of plasma resonance, called the plasmon resonance band (PRB) observed near $530 \mathrm{~nm}$ in the 5-20 $\mathrm{nm}$ diameter range. The plasmon resonance of nanoparticles is closely related to the size, shape and dielectric properties of the medium surrounding the nanoparticles [37]. By varying the shape of metal nanoparticles, such as nanospheres, nanotubes, nanoprisms or core-shell nanoparticles, their optical properties vary in a quantitative and dependent manner [38]. Gold nanoparticles are used as sensors for the early diagnosis of many diseases [39]. Alzheimer's disease and breast cancer have been targeted for essential early diagnosis [40]. With early diagnosis, current drugs have the ability to postpone the onset of symptoms typical of the disease [41] and are therefore essential for greater treatment efficacy and a higher survival rate [42]. Gold nanoshells have been used as theranostics for the diagnosis and photothermal therapy of breast cancer cells in vitro [40]. Gold nanoshells induce an important photothermal response under illumination of near infrared radiation, showing good potential for cancer therapy, with $100 \%$ efficacy in tumor remission [42,43]. The surfaces of gold nanoshells can link targeting, diagnostic and therapeutic functionalities, forming a multifunctional nanocomplex. This system has also been used in vivo, enriching the near infrared fluorescence and, at the same time, the magnetic resonance imaging capability [44]. A gold nanoparticle delivery system conjugated with gemcitabine and cetuximab as a target agent has been tested in vitro and in vivo for the treatment of pancreatic cancer cells [45]. The results of these tests showed a greater inhibition of tumor growth through a targeted system. The targeted release of multifunctional nanoparticles [46], obtained by conjugating three different peptides, was investigated: an epidermal growth factor receptor (EGFR)-recognizing peptide, an aminoterminal peptide that recognizes the urokinase plasminogen activator receptor and a peptide cyclic that recognizes the integrin receptor, to study the accumulation of gold in tumor models. These experiments did not demonstrate a substantial improvement in tumor uptake compared to control particles in vivo. Instead, gold nanoparticles with a thiolate derivative of cisplatin have been produced and tested against ovarian cancer cells [47]. The results showed that the gold conjugate with cisplatin had comparable efficacy to cisplatin alone, but toxicity to 
healthy cells was almost nothing, unlike the high toxicity of cisplatin used alone [48]. The decrease in toxicity towards healthy cells is one of the many reasons why therapies with gold nanoparticles can prove superior to the use of drugs alone [49]. In vivo studies have shown how multifunctional fluorescent magnetic nanocomplexes are used to trace the distribution of the nanocomplexes on tumor tissues. Nanocomplexes conjugated with specific antibodies targeting human epidermal growth factor receptor 2 (HER2) that overexpress breast cancer tumors could then be identified using magnetic resonance imaging (MRI) of the nanocomplex. As antibody-conjugated nanocomplexes are tracked throughout the body, we observe clear differences in the amounts of tumor uptake between over-expressed HER2 and low-expression HER2 tumors. This study demonstrated that it is possible to visualize tumors in vivo and that MRI could reveal a detailed picture of the distribution of nanoparticles in tumors and internal organs [50]. The diagnostic capabilities of the nanocomplexes have been visualized in vivo on HER2-expressing breast cancer tumors in animal models. Molecular targeting is achieved by combining anti-HER2 antibodies on the surface of the nanoparticle via the streptavidin-biotin binding procedure. In addition, poly ethylene glycol (PEG) conjugated to nanocomplexes is used to weaken nonspecific binding in vivo, to sterically stabilize the complexes, to implement circulation time, to lower immunogenicity and, in combination with antibodies, to increase accumulation of nanoparticles in the tumor [51]. Advantageous biological systems were investigated that exploit polyvalent interactions, allowing an organism to take advantage of a set of monovalent ligands with lower affinity, rather than using new and higher affinity monovalent ligands for each function. Ligand binding to a gold nanoparticle in the multivalent mode is an effective way to generate a high local concentration of ligands. The binding equilibria between the surface-bound ligand and the receptor can be shifted towards the formation of more ligand-receptor pairs in the presence of a high local ligand concentration according to the Le Chatelier principle [52].

One type of ligands, conjugated to gold nanoparticles, are carbazoles, extensively studied for their antioxidant and antimicrobial properties. Carbazole derivatives have also become important for their efficient inhibition of topoisomerase, tubulin, telomerase, kinase and integrase [53,54]. These compounds induce antiproliferative activity and a significant apoptotic response in a selective manner towards tumor cells [55-57]. The gold nanoparticles functionalized with $N$-thiocarbazole derivatives (Figure 2) have been employed as antiproliferative agents against breast and uterine cancer cell lines without affecting non-tumor cells [58].

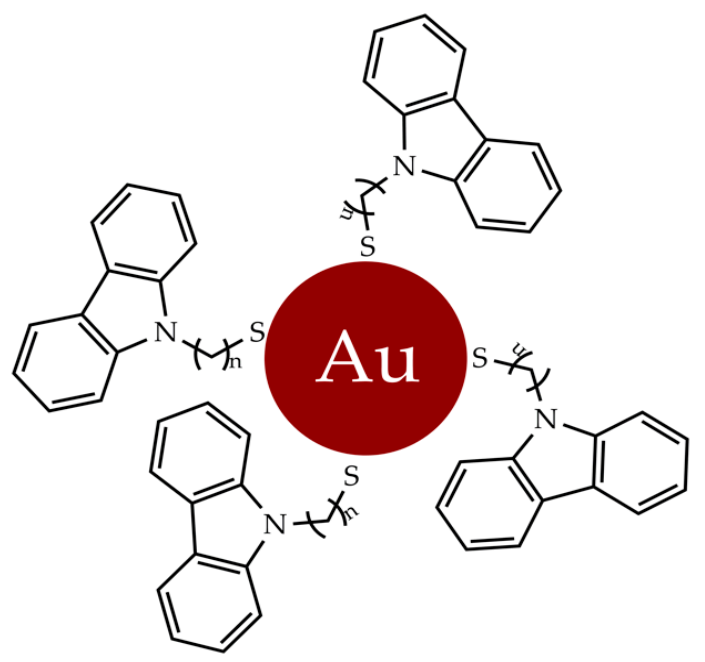

Figure 2. Gold nanoparticles functionalized with $N$-thioalkylcarbazole derivatives.

The unique properties of gold nanoparticles were exploited for detection assays, employing the nanoparticles as cell-permeable multivalent systems, and further investigating promising and targeted therapies for known receptors [59]. 


\section{Gold Complexes}

In recent decades, new gold complexes have been developed with antibacterial, antiviral, antiparasitic and antitumor activity [60]. Several intracellular protein targets, such as kinases, reductases, proteases and topoisomerases, interact with gold (III) complexes; in particular, the blocking of the latter leads to programmed cell death [61]. The ability of $\left[\mathrm{Au}\left(\mathrm{C}^{\wedge} \mathrm{N}^{\wedge} \mathrm{C}\right)(\mathrm{IMe})\right] \mathrm{CF}_{3} \mathrm{SO}_{3}$ (1) (Figure 3) to inhibit the relaxation reaction of supercoiled DNA was analyzed. By comparing the different electrophoretic mobility of both supercoiled and relaxed forms, it was shown that compound $\mathbf{1}$ was able to inhibit the relaxation activity of human IB topoisomerase.
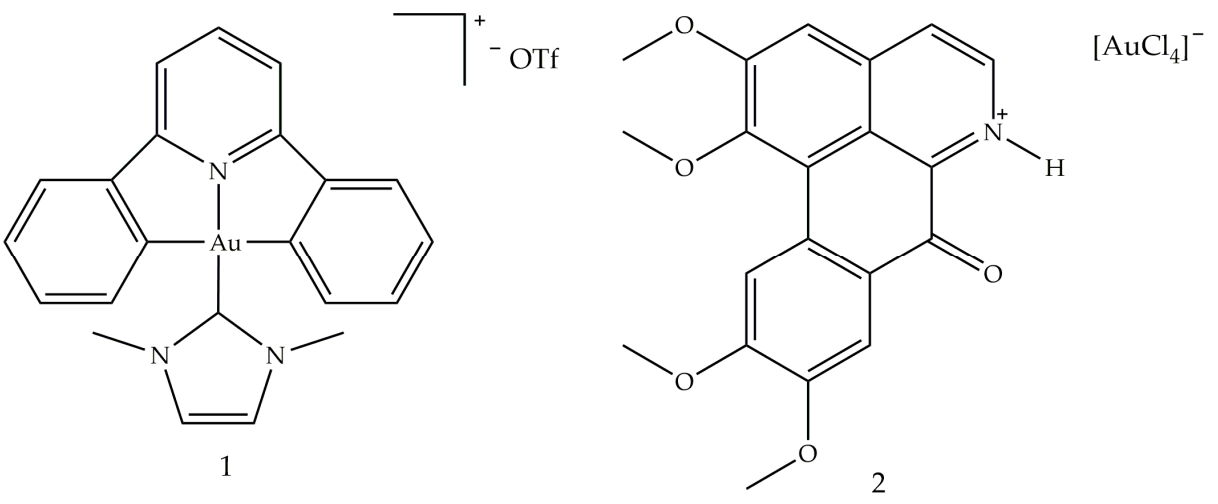

Figure 3. Molecular structure of $\left.\left[\mathrm{Au}\left(\mathrm{C}^{\wedge} \mathrm{N}^{\wedge} \mathrm{C}\right)(\mathrm{IMe})\right] \mathrm{CF}_{3} \mathrm{SO}_{3}\right](\mathbf{1})$ and $[\mathrm{OGH}]\left[\mathrm{AuCl}_{4}\right]$ (2) [60]. $\mathrm{Ab}-$ breviations: $\mathrm{C}^{\wedge} \mathrm{N}^{\wedge} \mathrm{C}$ is the bi-cyclometallated di-anionderived from 2,6-diphenylpyridine, IMe is $N, N^{\prime}$-dimethylimidazolium and [OGH](+) is the charged alkaloid oxoglaucine (OG).

A study conducted in 2012 described the use of oxoglaucine (OG) as a ligand, an alkaloid extract of oxoaporphine obtained from the overground parts of different plants, such as Annonaceae, Magnoliaceae and Papaveraceae [62]. The reaction was carried out between OG and a gold (III) salt, to obtain the complex of gold (III) (2), an ionic compound made up of the oxoglaucine cation and the anion $\left[\mathrm{AuCl}_{4}\right]^{-}$having a square planar structure (Figure 3). In this compound, the oxoglaucine is protonated on the nitrogen atom while the gold (III) tetrachloride acts as a counter ion, balancing the charge. Crystallographic data confirmed that oxoglaucine organizes itself into a planar structure, capable of intercalating DNA [63]. The ability of compound 2 to block tumor growth was evaluated in vitro against different cell lines where the best results were obtained for human papillomavirus-related endocervical adenocarcinoma BEL7404 cells, with an inhibitory concentration $\mathrm{IC}_{50}$ (i.e., the half maximal inhibitory concentration) of $6.1 \pm 0.5 \mu \mathrm{M}$ and for AS49 human lung carcinoma cells $\left(\mathrm{IC}_{50}=1.4 \pm 0.7 \mu \mathrm{M}\right)$ [62]. Figure 4 shows the square planar gold (III) chelates (3-6), synthesized by Wilson et al. [64], in which the pyridyl- or isoquinolylamide bidentate anionic chelators are used as ligands, in order to stabilize gold (III) through the presence of donor $\sigma$ atoms. Among these, only compound 6 showed a good cytotoxic profile, towards two ovarian cancer cells (OVCAR-3 and IGROV1, with $\mathrm{IC}_{50}$ values of 4.0 and $9.8 \mu \mathrm{M}$, respectively) and against one colon tumor cell line (SW-620, $\left.\mathrm{IC}_{50}=15 \mu \mathrm{M}\right)$. Compound 6 is both a topoisomerase IIa (TopoIIa) inhibitor, with a mechanism of action similar to that of zorubicin, and a TopoIB inhibitor, such as Topotecan and 9-methoxycamptothecin. Furthermore, this compound is structurally similar to cisplatin, but does not possess the same anticancer properties, probably due to the fact that the chloride ligands are not reactive. This condition could inhibit the replacement of water with the metal ion in vivo and the consequent formation of a gold (III)-DNA complex. Another study described the biological properties of a series of planar cationic $\mathrm{Au}^{3+}$ macrocycles containing two pyrroleimine units linked to a quinoxaline group and an alkyl chain. Among these molecules, shown in Figure 5, compound 7 showed the best antiproliferative activity, against different types of cell lines. Moreover, it exhibits a marked inhibition activity of TopoI at $500 \mathrm{nM}$ 
and a total inhibitor at the dose of $5 \mu \mathrm{M}$. In particular, the presence of gold (III) is crucial for the inhibition of topoisomerase and for DNA intercalation [65].

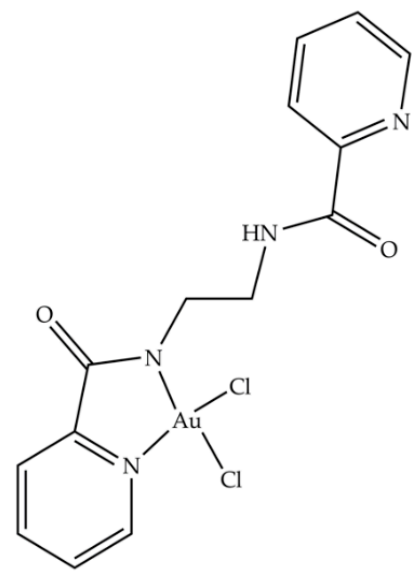

3

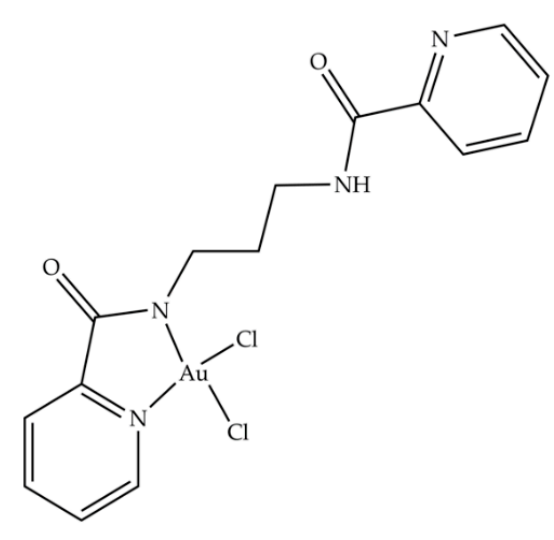

4

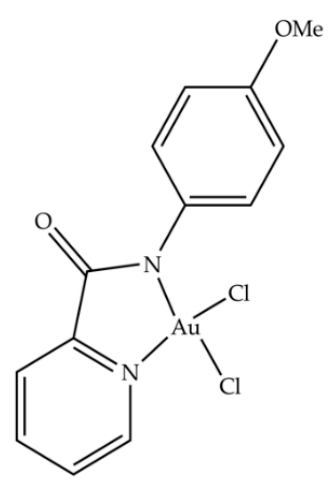

5

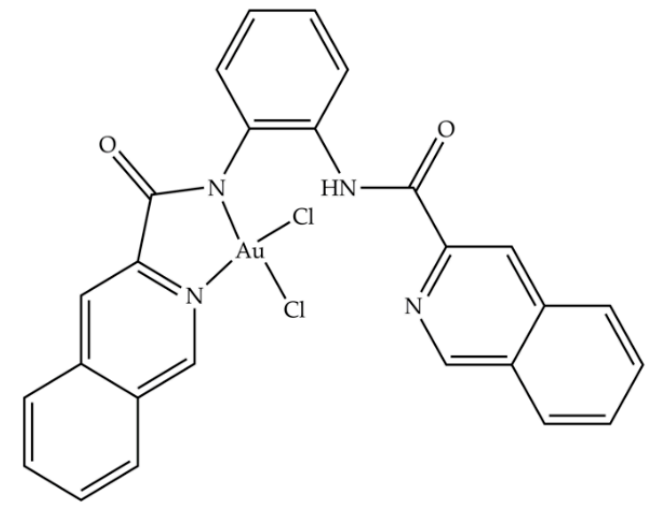

6

Figure 4. Molecular structures of gold (III) pyridyl and isoquinolylamido chelates (3-6) [60].

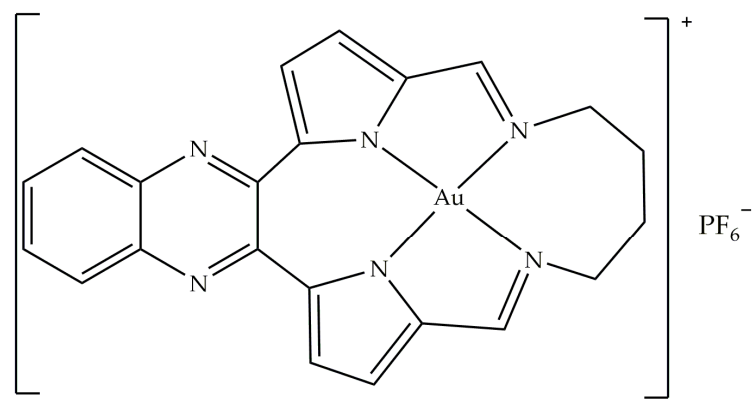

7

Figure 5. Molecular structure of the gold (III) macrocycle (7) [60].

Another study, conducted in 2016, ref. [66] focused on the synthesis of thiosemicarbazones coordinated with different metals ( $\mathrm{Pt}, \mathrm{Pd}$ and $\mathrm{Au})$. Among these, the complex with the best cytotoxic activity against leukemic cells (HL-60 and THP-1, with $\mathrm{IC}_{50}$ values of $0.26 \pm 0.20$ and $0.62 \pm 0.49 \mu \mathrm{M}$, respectively) and cancer cells breast (MDA-MB-231 and MCF-7, with $\mathrm{IC}_{50}$ values of $0.09 \pm 0.05$ and $0.42 \pm 0.01 \mu \mathrm{M}$, respectively) resulted in [Au $\left.\left(\mathrm{PyCT}_{4} \mathrm{BrPh}\right) \mathrm{Cl}\right] \mathrm{Cl}$ (8) (Figure 6). This compound 8 inhibits TopoIB as a function of the 
administered dose, with a small inhibition at $1.5 \mu \mathrm{mol} \mathrm{L}^{-1}$ and total inhibition starting at $50 \mu \mathrm{mol} \mathrm{L}{ }^{-1}$. This result could depend on the interaction of gold with the enzyme: in fact, thiosemicarbazone not coordinated with the metal is not able to inhibit TopoIB but could be the vehicle of the metal.

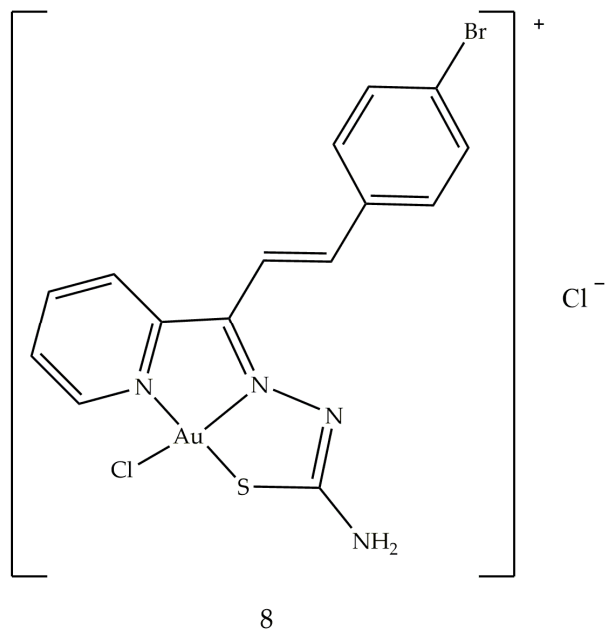

Figure 6. Molecular structure of the gold (III) thiosemicarbazone (8).

\section{Gold Based Carbene Complexes}

Heterocyclic and metallocene complexes have also been investigated for their potential antitumor activity [67-69]. These metal complexes have the general formula $\mathrm{L}_{\mathrm{n}} \mathrm{MX} \mathrm{X}_{\mathrm{m}}$, where $\mathrm{M}$ is the metal that constitutes the reactive center, in its oxidation state equal to $0, \mathrm{~L}$ is the carbene, which is the ligand able to influence the electronic properties of the metal and consequently, the possible catalytic activity of the complex and $\mathrm{X}$ is a non-carbenic ligand of anionic nature, such as a halide, a carboxylate or an alkoxide [70,71]. The stability and chemical reactivity of these complexes can be influenced by the covalent bonds coordinated with various transition metal centers through $\sigma$ donation and $\pi$-retro-donation, the aromaticity of the NHC ligand and the volume of the side chains [72]. Among these, heterocyclic gold $\mathrm{N}$-carbene (NHC) complexes attract particular interest in the pharmaceutical research sector, meeting the requirements for efficient and rapid drug design, and for thence to their chemical stability [73]. A number of gold NHC complexes have been biologically tested and, in particular, some of them have also shown anticancer effects in vitro. Au-NHC complexes offer a wide range of biological activities, such as antiarthritic [74], antimicrobial [75] and especially antitumor ones. The anticancer properties of Au (I/III)-NHC complexes have been studied in different cellular backgrounds, such as melanoma, breast, prostate and hepatocellular carcinoma cell lines. It has been shown that $\mathrm{Au}-\mathrm{NHC}$ complexes can differently affect cell cycle distribution, expressions of several key regulators of apoptosis, mitochondrial integrity, activation of caspases and generation of reactive intracellular oxygen species (ROS) [76]. The structures of these gold NHC complexes were synthesized to evaluate the influence of increased lipophilicity on their pharmacological effects [77]. The lipophilic cation, whose $\pi$-electrons are delocalized, can cross biological membranes more rapidly and concentrate within the mitochondria of cancer cells. The lipophilicity of the complex increases when the nitrogen atoms are functionalized with lipophilic substituents. The effect of different substituents on the $\mathrm{N}-1$ atom on pharmacological activity was tested. In particular, position 1 was functionalized with 2-cyclopentanol (L1), 2-cyclohexanol (L2) and 2-hydroxy-2-phenylethyl (L3) while in position 3 a methyl group was always present (Figure 7). The obtained complexes were studied for their anticancer properties against human breast cancer cells and the underlying molecular mechanism was studied in detail by biological assays and macromolecular docking studies, in order to understand the probable ligand-protein binding modes. One of the tested compounds, AuL3, showed good 
growth inhibitory activity by inducing apoptosis of breast cancer cells, without exerting any effect on healthy breast epithelial cells.<smiles></smiles>

$\mathrm{R}$

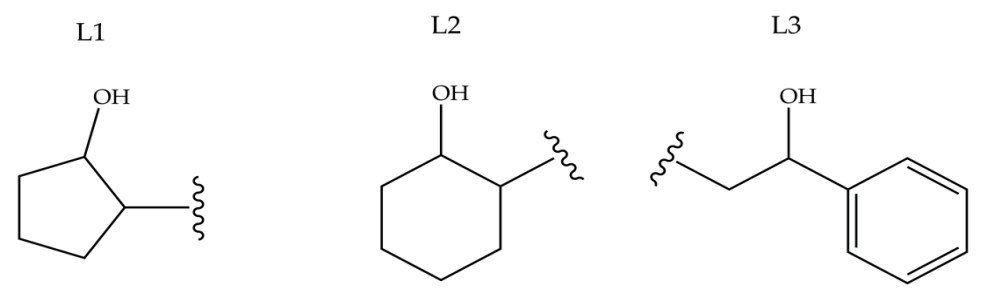

Figure 7. NH-Carbene proligands L1, L2 and L3, employed in AuL $(n=1-3)$ complexes.

The antitumor activity of these complexes was evaluated on two breast cancer cell lines, MCF-7 and MDA-MB-231. The results obtained highlighted an interesting antitumor activity of the compounds shown in Figure 8, in particular on the highly aggressive and metastatic MDA-MB-231 cell line. In vitro studies have shown that these compounds are able to interfere with tubulin polymerization by inhibiting the activity of hTopo I and II, already at the minimum concentration of $1 \mathrm{M}$. Therefore, these results have shown that these compounds may be useful for further future investigations enabling the development of new multitarget agents in the treatment of breast cancer.

\section{Antiarthritic Gold Compounds in Oncology}

The treatment of different tumors with cisplatin, $\left(\mathrm{NH}_{3}\right)_{2} \mathrm{PtCl}_{2}$, has initiated and focused the pharmacological research towards metal-based drugs, such as gold (I, III) compounds, in particular, those that exhibit antiarthritic, antitumor and cytotoxic activity. The study of the effectiveness of anticancer drugs, e.g., 6-mercaptopurine and cyclophosphamide, in the treatment of rheumatoid arthritis, derived from their known immunosuppressive and anti-inflammatory actions $[78,79]$. This study established a connection between the two therapies, antiarthritic and antitumor. One of the reasons why scientific research has become interested in gold compounds is their square planar geometry, which unites them to platinum in cisplatin. Gold (III) is isoelectronic with platinum (II) in cisplatin and also forming similar planar square complexes. Furthermore, the biological environment is generally reducing, so gold (III) compounds can be reduced in vivo to gold (I) and metallic gold. By coordinating bioactive molecules with gold, it is possible to obtain compounds having greater activity and therapeutic effect than uncoordinated molecules. Promising in vitro inhibitory effects of auranofin (Figure 8b) against HeLa cells [80] and subsequent research on its antitumor activity were investigated. The in vitro cytotoxic activity of auranofin, tested on various cell lines, was similar or even greater than cisplatin (Figure 8a). 


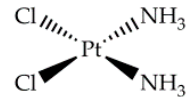

cisplatin

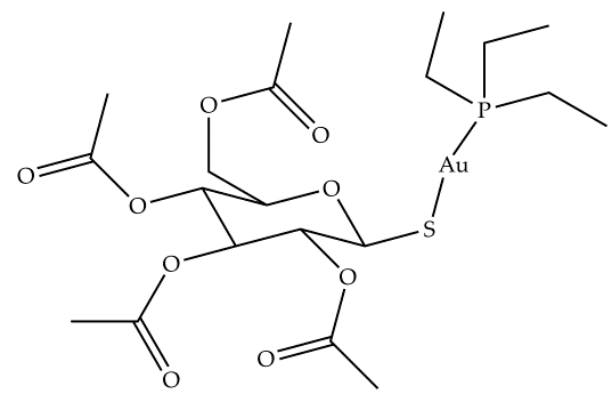

Auranofin

b)

Figure 8. Chemical structure of (a) cisplatin and (b) auranofin.

A good cytotoxic activity was also evaluated in vivo against P388 lymphocytic leukemia implanted in mice [81]. Several gold (I) thiolates have been tested for their anticancer activity. Aurothioglucose (Figure 9a) and aurothiomalate (Figure 9b) inhibited primary tumor growth in mice with Lewis carcinoma and reduced lung metastases [81]. Unlike cisplatin (6), aurothiomalate did not exhibit acute toxicity in vivo.

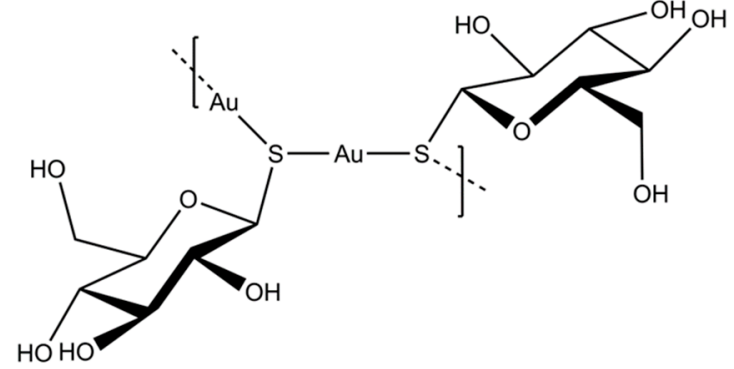

Aurothioglucose

a)

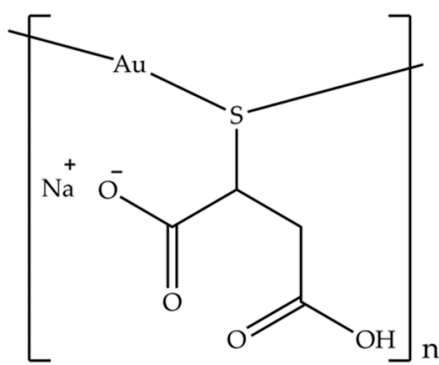

Sodium aurothiomalate

b)

Figure 9. Chemical structure of (a) aurothioglucose and (b) sodium aurothiomalate.

The in vitro cytotoxicity of several gold compounds against B16 melanoma and P388 leukemic cells was examined in a study of auranofin and similar compounds [81]. The result shows that a wide variety of gold (I) phosphine thiolates possesses a significant cytotoxic activity. The presence of a phosphine or arsine as a binder has resulted in an increase in cytotoxicity and in vivo antitumor activity against P388 leukemia, compared to other species. The importance of the type of phosphine, used in the binuclear gold (I) compounds containing bidentate phosphines, was tested in vivo against leukemia P388, by systematically varying the nature of the phosphine and keeping the thiolate, $\mathrm{R}^{-} \mathrm{S}^{-}$, constant. The most active compound was the one containing $\left(\mathrm{CH}_{3} \mathrm{CH}_{2}\right)\left[\left(\mathrm{CH}_{3}\right)_{2} \mathrm{CH}\right] \mathrm{P}$ (Figure 10a), while the least active one had $\left(\mathrm{C}_{6} \mathrm{H}_{5}\right)_{2} \mathrm{P}$ (Figure 10b). 
<smiles>[R5][Al]P(CC)(CC)(CCC)C(C)C</smiles>

a)<smiles>CP([Al][As])(c1ccccc1)(c1ccccc1)c1ccccc1</smiles>

b)

Figure 10. Structures of binuclear gold (I) compounds containing bidentate phosphines (a) $\left(\mathrm{CH}_{3} \mathrm{CH}_{2}\right)\left[\left(\mathrm{CH}_{3}\right)_{2} \mathrm{CH}\right] \mathrm{P}$ and $(\mathbf{b})\left(\mathrm{C}_{6} \mathrm{H}_{5}\right)_{2} \mathrm{P}$.

In summary, it can be stated that the most active class, among the compounds examined, was the one containing both phosphine and thioglucose ligands. The cytotoxicity and antitumor activity of several gold compounds with phosphine binders was tested and proved cytotoxic against B16 melanoma, subcutaneous breast adenocarcinoma, M5076 reticulum cell sarcoma leukemia and P388 and L1210 leukemia [82]. In addition, two new 1-acridin-9-yl-3-methylthiourea complexes $\mathrm{Au}(\mathrm{I}),\left[\mathrm{Au}(\mathrm{ACRTU})_{2}\right] \mathrm{Cl}(9)$ and $[\mathrm{Au}$ $\left.(\mathrm{ACRTU})\left(\mathrm{PPh}_{3}\right)\right] \mathrm{PF}_{6}(\mathbf{1 0})$ (Figure 11), showed submicromolar cytotoxic activity against A2780 ovarian cancer cells and antiproliferative activity, superior to cisplatin, against some breast cancer cell lines, with a potent antiangiogenic effect. Compound 9 showed the best inhibitory effect, completely relaxing the supercoiled plasmid DNA at the concentration of $12 \mu \mathrm{M}$.<smiles>CNC(=S)Nc1c2ccccc2nc2ccccc12</smiles>

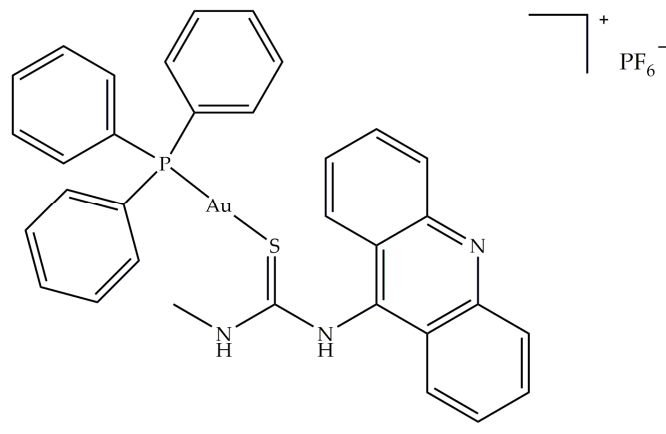

10

Figure 11. Molecular structure of acridine thiourea gold (I) (9 and 10).

\section{Conclusions}

The fight against cancer is a problem that requires a combination of different therapies. Scientific research has focused on the study of gold compounds that show selectivity and 
cytotoxicity towards cisplatin-resistant tumors, and affinity for biological targets such as mitochondria and DNA. This study moved towards the personalization of therapy, to obtain targeted treatments, with greater selectivity and fewer toxic effects. This review summarized the cytotoxic and antitumor activity of some gold derivatives, from nanoparticles to complexes, highlighting their action in blocking human topoisomerases, vital enzymes involved in the proliferation of cancer cells, validating their potential as antitumor agents. All the compounds discussed in this review showed interesting anticancer properties against breast and uterine cancer and were very active against the proliferation of HeLa cells. Further investigations revealed that these derivatives caused the destruction of mitochondria and the release of cytochrome $\mathrm{c}$ from its natural site, inducing the activation of enzymes belonging to the intrinsic pathway of apoptosis in a ROS-dependent manner. These characteristics, together with the absence of cytotoxic effects on two different non-tumor cells, make these derivatives very promising and valid candidates for the development of gold-based antitumor drugs and for further preclinical investigations.

Author Contributions: Conceptualization was done by M.S.S., G.R. and M.R.P. Investigation was performed by I.I., D.I., M.G., D.D. Project administration was directed by P.L., C.S., M.S.S., G.R. and M.R.P. Resources were provided by I.I., D.I., C.S., P.L., M.G., D.D., G.R., M.S.S., M.R.P. Supervision was taken care of by M.S.S., G.R. and M.R.P. Validation was carried out by D.I., I.I. Visualization and original draft writing was done by I.I., D.I., M.S.S., G.R. and M.R.P. All authors have read and agreed to the published version of the manuscript.

Funding: This research received no external funding.

Institutional Review Board Statement: Not applicable.

Informed Consent Statement: Not applicable.

Data Availability Statement: Not applicable.

Acknowledgments: MURST: CNR and MIUR are gratefully acknowledged for financial support.

Conflicts of Interest: The authors declare no conflict of interest.

\section{References}

1. Prager, G.W.; Braga, S.; Bystricky, B.; Qvortrup, C.; Criscitiello, C.; Esin, E.; Sonke, G.S.; Martínez, G.A.; Frenel, J.-S.; Karamouzis, M.; et al. Global cancer control: Responding to the growing burden, rising costs and inequalities in access. ESMO Open 2018, 3, e000285. [CrossRef] [PubMed]

2. Ferlay, J.; Soerjomataram, I.; Dikshit, R.; Eser, S.; Mathers, C.; Rebelo, M.; Parkin, D.M.; Forman, D.; Bray, F. Cancer incidence and mortality worldwide: Sources, methods and major patterns in GLOBOCAN 2012. Int. J. Cancer 2014, 136, E359-E386. [CrossRef] [PubMed]

3. Rizza, P.; Pellegrino, M.; Caruso, A.; Iacopetta, D.; Sinicropi, M.S.; Rault, S.; Lancelot, J.C.; El-Kashef, H.; Lesnard, A.; Rochais, C.; et al. 3-(Dipropylamino)-5-hydroxybenzofuro[2,3-f]quinazolin-1(2H)-one (DPA-HBFQ-1) plays an inhibitory role on breast cancer cell growth and progression. Eur. J. Med. Chem. 2016, 107, 275-287. [CrossRef]

4. Nagajyothi, P.; Muthuraman, P.; Sreekanth, T.; Kim, D.H.; Shim, J. Green synthesis: In-vitro anticancer activity of copper oxide nanoparticles against human cervical carcinoma cells. Arab. J. Chem. 2017, 10, 215-225. [CrossRef]

5. Husinka, L.; Koerner, P.H.; Miller, R.T.; Trombatt, W. Review of cyclin-dependent kinase $4 / 6$ inhibitors in the treatment of advanced or metastatic breast cancer. J. Drug Assess. 2021, 10, 27-34. [CrossRef] [PubMed]

6. Spring, L.M.; Wander, S.A.; Zangardi, M.; Bardia, A. CDK 4/6 Inhibitors in Breast Cancer: Current Controversies and Future Directions. Curr. Oncol. Rep. 2019, 21, 1-9. [CrossRef] [PubMed]

7. Marra, A.; Curigliano, G. Are all cyclin-dependent kinases $4 / 6$ inhibitors created equal? NPJ Breast Cancer 2019, 5, 1-9. [CrossRef]

8. Miller, T.W.; Balko, J.M.; Fox, E.M.; Ghazoui, Z.; Dunbier, A.; Anderson, H.; Dowsett, M.; Jiang, A.; Smith, R.A.; Maira, S.-M.; et al. ER $\alpha$-Dependent E2F Transcription Can Mediate Resistance to Estrogen Deprivation in Human Breast Cancer. Cancer Discov. 2011, 1, 338-351. [CrossRef] [PubMed]

9. Im, S.-A.; Lu, Y.-S.; Bardia, A.; Harbeck, N.; Colleoni, M.; Franke, F.; Chow, L.; Sohn, J.; Lee, K.-S.; Campos-Gomez, S.; et al. Overall Survival with Ribociclib plus Endocrine Therapy in Breast Cancer. N. Engl. J. Med. 2019, 381, 307-316. [CrossRef] [PubMed]

10. Finn, R.S.; Martin, M.; Rugo, H.S.; Jones, S.E.; Im, S.-A.; Gelmon, K.A.; Harbeck, N.; Lipatov, O.N.; Walshe, J.M.; Moulder, S.L.; et al. PALOMA-2: Primary results from a phase III trial of palbociclib (P) with letrozole (L) compared with letrozole alone in postmenopausal women with ER+/HER2- advanced breast cancer (ABC). J. Clin. Oncol. 2016, 34, 507. [CrossRef] 
11. Verma, S.; Bartlett, C.H.; Schnell, P.; DeMichele, A.M.; Loi, S.; Ro, J.; Colleoni, M.; Iwata, H.; Harbeck, N.; Cristofanilli, M.; et al. Palbociclib in Combination with Fulvestrant in Women with Hormone Receptor-Positive/HER2-Negative Advanced Metastatic Breast Cancer: Detailed Safety Analysis From a Multicenter, Randomized, Placebo-Controlled, Phase III Study (PALOMA-3). Oncologist 2016, 21, 1165-1175. [CrossRef] [PubMed]

12. Paranjpe, R.; John, G.; Trivedi, M.; Abughosh, S. Identifying adherence barriers to oral endocrine therapy among breast cancer survivors. Breast Cancer Res. Treat. 2018, 174, 297-305. [CrossRef]

13. Cafeo, G.; Carbotti, G.; Cuzzola, A.; Fabbi, M.; Ferrini, S.; Kohnke, F.H.; Papanikolaou, G.; Plutino, M.R.; Rosano, C.; White, A.J.P. Drug Delivery with a Calixpyrrole-trans-Pt(II) Complex. J. Am. Chem. Soc. 2013, 135, 2544-2551. [CrossRef]

14. Saturnino, C.; Napoli, M.; Paolucci, G.; Bortoluzzi, M.; Popolo, A.; Pinto, A.; Longo, P. Synthesis and cytotoxic activities of group 3 metal complexes having monoanionic tridentate ligands. Eur. J. Med. Chem. 2010, 45, 4169-4174. [CrossRef] [PubMed]

15. Romeo, R.; Scolaro, L.M.; Plutino, M.R.; Albinati, A. Structural properties of the metallointercalator cationic complex $\left(2,2^{\prime}: 6^{\prime}, 2^{\prime \prime}-\right.$ terpyridine)methylplatinum(II) ion. J. Organomet. Chem. 2000, 593, 403-408. [CrossRef]

16. Malik, P.; Mukherjee, T.K. Recent advances in gold and silver nanoparticle based therapies for lung and breast cancers. Int. J. Pharm. 2018, 553, 483-509. [CrossRef]

17. Langer, C.J.; Gadgeel, S.M.; Borghaei, H.; Papadimitrakopoulou, V.A.; Patnaik, A.; Powell, S.F.; Gentzler, R.D.; Martins, R.G.; Stevenson, J.P.; I Jalal, S.; et al. Carboplatin and pemetrexed with or without pembrolizumab for advanced, non-squamous non-small-cell lung cancer: A randomised, phase 2 cohort of the open-label KEYNOTE-021 study. Lancet Oncol. 2016, 17, 1497-1508. [CrossRef]

18. Cohen, H.; Levy, R.J.; Gao, J.; Fishbein, I.; Kousaev, V.; Sosnowski, S.; Slomkowski, S.; Golomb, G. Sustained delivery and expression of DNA encapsulated in polymeric nanoparticles. Gene Ther. 2000, 7, 1896-1905. [CrossRef]

19. Gref, R.; Minamitake, Y.; Peracchia, M.T.; Trubetskoy, V.; Torchilin, V.; Langer, R.; Kamb, A.; Gruis, N.; Weaver-Feldhaus, J.; Liu, Q.; et al. Biodegradable long-circulating polymeric nanospheres. Science 1994, 263, 1600-1603. [CrossRef] [PubMed]

20. Zanella, A.; Gandin, V.; Porchia, M.; Refosco, F.; Tisato, F.; Sorrentino, F.; Scutari, G.; Rigobello, M.P.; Marzano, C. Cytotoxicity in human cancer cells and mitochondrial dysfunction induced by a series of new copper(I) complexes containing tris(2-cyanoethyl)phosphines. Investig. New Drugs 2010, 29, 1213-1223. [CrossRef]

21. Dhanyalayam, D.; Scrivano, L.; Parisi, O.I.; Sinicropi, M.S.; Fazio, A.; Saturnino, C.; Plutino, M.R.; Di Cristo, F.; Puoci, F.; Cappello, A.R.; et al. Biopolymeric self-assembled nanoparticles for enhanced antibacterial activity of Ag-based compounds. Int. J. Pharm. 2017, 517, 395-402. [CrossRef] [PubMed]

22. Tiekink, E.R. Gold derivatives for the treatment of cancer. Crit. Rev. Oncol. 2002, 42, 225-248. [CrossRef]

23. Kumar, A.; Boruah, B.M.; Liang, X.-J. Gold Complexes as Prospective Metal-Based Anticancer Drugs. Encycl. Met. 2013, 23, 867-875. [CrossRef]

24. Claffey, J.; Gleeson, B.; Hogan, M.; Müller-Bunz, H.; Wallis, D.; Tacke, M. Fluorinated Derivatives of Titanocene Y: Synthesis and Cytotoxicity Studies. Eur. J. Inorg. Chem. 2008, 2008, 4074-4082. [CrossRef]

25. Kudgus, R.A.; Bhattacharya, R.; Mukherjee, P. Cancer nanotechnology: Emerging role of gold nanoconjugates. Anti-Cancer Agents Med. Chem. 2011, 11, 965-973. [CrossRef] [PubMed]

26. Maeda, H.; Wu, J.; Sawa, T.; Matsumura, Y.; Hori, K. Tumor vascular permeability and the EPR effect in macromolecular therapeutics: A review. J. Control. Release 2000, 65, 271-284. [CrossRef]

27. Brigger, I.; Dubernet, C.; Couvreur, P. Nanoparticles in cancer therapy and diagnosis. Adv. Drug Deliv. Rev. 2012, 64, 24-36. [CrossRef]

28. Fenart, L.; Casanova, A.; Dehouck, B.; Duhem, C.; Slupek, S.; Cecchelli, R.; Betbeder, D. Evaluation of effect of charge and lipid coating on ability of 60-nm nanoparticles to cross an in vitro model of the blood-brain barrier. J. Pharmacol. Exp. Ther. 1999, 291, 1017-1022. [PubMed]

29. Huynh, N.; Passirani, C.; Saulnier, P.; Benoit, J. Lipid nanocapsules: A new platform for nanomedicine. Int. J. Pharm. 2009, 379, 201-209. [CrossRef]

30. Maeda, H. Tumor-Selective Delivery of Macromolecular Drugs via the EPR Effect: Background and Future Prospects. Bioconjugate Chem. 2010, 21, 797-802. [CrossRef]

31. Cho, K.; Wang, X.; Nie, S.; Chen, Z.; Shin, D.M. Therapeutic Nanoparticles for Drug Delivery in Cancer. Clin. Cancer Res. 2008, 14, 1310-1316. [CrossRef]

32. Iacopetta, D.; Grande, F.; Caruso, A.; Mordocco, R.A.; Plutino, M.R.; Scrivano, L.; Ceramella, J.; Muià, N.; Saturnino, C.; Puoci, F.; et al. New insights for the use of quercetin analogs in cancer treatment. Future Med. Chem. 2017, 9, 2011-2028. [CrossRef]

33. Misra, R.; Acharya, S.; Sahoo, S.K. Cancer nanotechnology: Application of nanotechnology in cancer therapy. Drug Discov. Today 2010, 15, 842-850. [CrossRef]

34. Murphy, C.J.; Gole, A.M.; Stone, J.W.; Sisco, P.N.; Alkilany, A.M.; Goldsmith, E.C.; Baxter, S.C. Gold Nanoparticles in Biology: Beyond Toxicity to Cellular Imaging. Accounts Chem. Res. 2008, 41, 1721-1730. [CrossRef]

35. Bhattacharya, R.; Mukherjee, P.; Xiong, Z.; Atala, A.; Soker, A.S.; Mukhopadhyay, D. Gold Nanoparticles Inhibit VEGF165-Induced Proliferation of HUVEC Cells. Nano Lett. 2004, 4, 2479-2481. [CrossRef]

36. Daniel, M.-C.; Astruc, D. Gold Nanoparticles: Assembly, Supramolecular Chemistry, Quantum-Size-Related Properties, and Applications toward Biology, Catalysis, and Nanotechnology. Chem. Rev. 2004, 104, 293-346. [CrossRef] [PubMed] 
37. Brust, M.; Kiely, C.J. Some recent advances in nanostructure preparation from gold and silver particles: A short topical review. Colloids Surf. A Physicochem. Eng. Asp. 2002, 202, 175-186. [CrossRef]

38. McConnell, W.P.; Novak, J.P.; Brousseau, L.C.; Fuierer, R.R.; Tenent, R.C.; Feldheim, D.L. Electronic and Optical Properties of Chemically Modified Metal Nanoparticles and Molecularly Bridged Nanoparticle Arrays. J. Phys. Chem. B 2000, 104, 8925-8930. [CrossRef]

39. Chen, W.; Bardhan, R.; Bartels, M.; Perez-Torres, C.; Pautler, R.G.; Halas, N.J.; Joshi, A. A Molecularly Targeted Theranostic Probe for Ovarian Cancer. Mol. Cancer Ther. 2010, 9, 1028-1038. [CrossRef]

40. Bardhan, R.; Chen, W.; Bartels, M.; Perez-Torres, C.; Botero, M.F.; McAninch, R.W.; Contreras, A.; Schiff, R.; Pautler, R.G.; Halas, N.J.; et al. Tracking of Multimodal Therapeutic Nanocomplexes Targeting Breast Cancer in Vivo. Nano Lett. 2010, 10, 4920-4928. [CrossRef]

41. Quinn, J.F.; Raman, R.; Thomas, R.G.; Yurko-Mauro, K.; Nelson, E.B.; Van Dyck, C.; Galvin, J.E.; Emond, J.; Jack, C.R.; Weiner, M.; et al. Docosahexaenoic Acid Supplementation and Cognitive Decline in Alzheimer Disease. JAMA 2010, 304, $1903-1911$. [CrossRef]

42. Lu, W.; Arumugam, S.R.; Senapati, D.; Singh, A.K.; Arbneshi, T.; Khan, S.A.; Yu, H.; Ray, P.C.; Yu, S.A.K.H. Multifunctional Oval-Shaped Gold-Nanoparticle-Based Selective Detection of Breast Cancer Cells Using Simple Colorimetric and Highly Sensitive Two-Photon Scattering Assay. ACS Nano 2010, 4, 1739-1749. [CrossRef]

43. Choi, M.-R.; Stanton-Maxey, K.J.; Stanley, J.K.; Levin, C.S.; Bardhan, R.; Akin, D.; Badve, S.; Sturgis, J.; Robinson, J.P.; Bashir, R.; et al. A Cellular Trojan Horse for Delivery of Therapeutic Nanoparticles into Tumors. Nano Lett. 2007, 7, 3759-3765. [CrossRef]

44. Kim, D.; Jeong, Y.Y.; Jon, S. A Drug-Loaded Aptamer-Gold Nanoparticle Bioconjugate for Combined CT Imaging and Therapy of Prostate Cancer. ACS Nano 2010, 4, 3689-3696. [CrossRef]

45. Patra, C.R.; Bhattacharya, R.; Wang, E.; Katarya, A.; Lau, J.S.; Dutta, S.; Muders, M.H.; Wang, S.; Buhrow, S.A.; Safgren, S.L.; et al. Targeted Delivery of Gemcitabine to Pancreatic Adenocarcinoma Using Cetuximab as a Targeting Agent. Cancer Res. 2008, 68, 1970-1978. [CrossRef]

46. El-Sayed, I.H.; Huang, X.; El-Sayed, M.A. Selective laser photo-thermal therapy of epithelial carcinoma using anti-EGFR antibody conjugated gold nanoparticles. Cancer Lett. 2006, 239, 129-135. [CrossRef] [PubMed]

47. Patra, C.R.; Bhattacharya, R.; Mukherjee, P. Fabrication and functional characterization of goldnanoconjugates for potential application in ovarian cancer. J. Mater. Chem. 2009, 20, 547-554. [CrossRef] [PubMed]

48. De Luca, G.; Bonaccorsi, P.; Trovato, V.; Mancuso, A.; Papalia, T.; Pistone, A.; Casaletto, M.P.; Mezzi, A.; Brunetti, B.; Minuti, L.; et al. Tripodal tris-disulfides as capping agents for a controlled mixed functionalization of gold nanoparticles. New J. Chem. 2018, 42, 16436-16440. [CrossRef]

49. Priya, M.R.K.; Iyer, P.R. Antiproliferative effects on tumor cells of the synthesized gold nanoparticles against Hep2 liver cancer cell line. Egypt. Liver J. 2020, 10, 1-12. [CrossRef]

50. Bardhan, R.; Chen, W.; Perez-Torres, C.; Bartels, M.; Huschka, R.M.; Zhao, L.L.; Morosan, E.; Pautler, R.G.; Joshi, A.; Halas, N.J. Nanoshells with Targeted Simultaneous Enhancement of Magnetic and Optical Imaging and Photothermal Therapeutic Response. Adv. Funct. Mater. 2009, 19, 3901-3909. [CrossRef]

51. Akiyama, Y.; Mori, T.; Katayama, Y.; Niidome, T. The effects of PEG grafting level and injection dose on gold nanorod biodistribution in the tumor-bearing mice. J. Control. Release 2009, 139, 81-84. [CrossRef] [PubMed]

52. Mammen, M.; Choi, S.K.; Whitesides, G.M. Polyvalent interactions in biological systems: Implications for design and use of multivalent ligands and inhibitors. Angew. Chem. 1998, 37, 2754-2794. [CrossRef]

53. Sinicropi, M.S.; Iacopetta, D.; Rosano, C.; Randino, R.; Caruso, A.; Saturnino, C.; Muià, N.; Ceramella, J.; Puoci, F.; Rodriquez, M.; et al. N-thioalkylcarbazoles derivatives as new anti-proliferative agents: Synthesis, characterisation and molecular mechanism evaluation. J. Enzym. Inhib. Med. Chem. 2018, 33, 434-444. [CrossRef]

54. Iacopetta, D.; Rosano, C.; Puoci, F.; Parisi, O.I.; Saturnino, C.; Caruso, A.; Longo, P.; Ceramella, J.; Malzert-Fréon, A.; Dallemagne, P.; et al. Multifaceted properties of 1,4-dimethylcarbazoles: Focus on trimethoxybenzamide and trimethoxyphenylurea derivatives as novel human topoisomerase II inhibitors. Eur. J. Pharm. Sci. 2017, 96, 263-272. [CrossRef] [PubMed]

55. Caruso, A.; Voisin-Chiret, A.S.; Lancelot, J.-C.; Sinicropi, M.S.; Garofalo, A.; Raulta, S. Novel and Efficient Synthesis of 5,8dimethyl-9hcarbazol- 3-ol via a hydroxydeboronation reaction. Molecules 2007, 71, 2203-2210.

56. Sinicropi, M.S.; Lappano, R.; Caruso, A.; Santolla, M.F.; Pisano, A.; Rosano, C.; Capasso, A.; Panno, A.; Lancelot, J.C.; Rault, S.; et al. (6-Bromo-1,4-dimethyl-9H-carbazol-3-yl-methylene)-hydrazine (Carbhydraz) Acts as a GPER Agonist in Breast Cancer Cells. Curr. Top. Med. Chem. 2015, 15, 1035-1042. [CrossRef] [PubMed]

57. Saturnino, C.; Caruso, A.; Longo, P.; Capasso, A.; Pingitore, A.; Caroleo, M.; Cione, E.; Perri, M.; Nicolo, F.; Nardo, V.; et al. Crystallographic Study and Biological Evaluation of 1,4-dimethyl-N-alkylcarbazolest. Curr. Top. Med. Chem. 2015, 15, 973-979. [CrossRef]

58. Saturnino, C.; Sinicropi, M.S.; Iacopettab, D.; Ceramella, J.; Caruso, A.; Muià, N.; Longo, P.; Rosace, G.; Galletta, M.; Ielo, I.; et al. N-Thiocarbazole-based gold nanoparticles: Synthesis, characterization and anti-proliferative activity evaluation. IOP Conf. Ser. Mater. Sci. Eng. 2018, 459, 012023. [CrossRef]

59. Mook-Jung, I.; Han, S.-H.; Chang, Y.J.; Jung, E.S.; Kim, J.-W.; Na, D.L. Effective screen for amyloid $\beta$ aggregation inhibitor using amyloid $\beta$-conjugated gold nanoparticles. Int. J. Nanomed. 2010, 6, 1-12. [CrossRef] 
60. Ceramella, J.; Mariconda, A.; Iacopetta, D.; Saturnino, C.; Barbarossa, A.; Caruso, A.; Rosano, C.; Sinicropi, M.S.; Longo, P. From coins to cancer therapy: Gold, silver and copper complexes targeting human topoisomerases. Bioorganic Med. Chem. Lett. 2020, 30, 126905. [CrossRef]

61. Kilpin, K.J.; Dyson, P.J. Enzyme inhibition by metal complexes: Concepts, strategies and applications. Chem. Sci. 2013, 4, 1410-1419. [CrossRef]

62. Chen, Z.-F.; Shi, Y.-F.; Liu, Y.-C.; Hong, X.; Geng, B.; Peng, Y.; Liang, H. TCM Active Ingredient Oxoglaucine Metal Complexes: Crystal Structure, Cytotoxicity, and Interaction with DNA. Inorg. Chem. 2012, 51, 1998-2009. [CrossRef] [PubMed]

63. Saturnino, C.; Popolo, A.; Ramunno, A.; Adesso, S.; Pecoraro, M.; Plutino, M.R.; Rizzato, S.; Albinati, A.; Marzocco, S.; Sala, M.; et al. Anti-Inflammatory, Antioxidant and Crystallographic Studies of N-Palmitoyl-ethanol Amine (PEA) Derivatives. Molecules 2017, 22, 616. [CrossRef]

64. Wilson, C.R.; Fagenson, A.M.; Ruangpradit, W.; Muller, M.T.; Munro, O.Q. Gold(III) Complexes of Pyridyl- and Isoquinolylamido Ligands: Structural, Spectroscopic, and Biological Studies of a New Class of Dual Topoisomerase I and II Inhibitors. Inorg. Chem. 2013, 52, 7889-7906. [CrossRef]

65. Chimento, A.; Saturnino, C.; Iacopetta, D.; Mazzotta, R.; Caruso, A.; Plutino, M.R.; Mariconda, A.; Ramunno, A.; Sinicropi, M.S.; Pezzi, V.; et al. Inhibition of human topoisomerase I and II and anti-proliferative effects on MCF-7 cells by new titanocene complexes. Bioorganic Med. Chem. 2015, 23, 7302-7312. [CrossRef] [PubMed]

66. Sâmia, L.B.P.; Parrilha, G.L.; Da Silva, J.G.; Ramos, J.P.; Souza-Fagundes, E.M.; Castelli, S.; Vutey, V.; Desideri, A.; Beraldo, H. Metal complexes of 3-(4-bromophenyl)-1-pyridin-2-ylprop-2-en-1-one thiosemicarbazone: Cytotoxic activity and investigation on the mode of action of the gold(III) complex. BioMetals 2016, 29, 515-526. [CrossRef]

67. Saturnino, C.; Barone, I.; Iacopetta, D.; Mariconda, A.; Sinicropi, M.S.; Rosano, C.; Campana, A.; Catalano, S.; Longo, P.; Andò, S. $\mathrm{N}$-heterocyclic carbene complexes of silver and gold as novel tools against breast cancer progression. Future Med. Chem. 2016, 8, 2213-2229. [CrossRef] [PubMed]

68. Napoli, M.; Saturnino, C.; Sirignano, E.; Popolo, A.; Pinto, A.; Longo, P. Synthesis, characterization and cytotoxicity studies of methoxy alkyl substituted metallocenes. Eur. J. Med. Chem. 2011, 46, 122-128. [CrossRef]

69. Caporale, A.; Palma, G.; Mariconda, A.; Del Vecchio, V.; Iacopetta, D.; Parisi, O.I.; Sinicropi, M.S.; Puoci, F.; Arra, C.; Longo, P.; et al. Synthesis and Antitumor Activity of New Group 3 Metallocene Complexes. Molecules 2017, 22, 526. [CrossRef]

70. Sirignano, E.; Saturnino, C.; Botta, A.; Sinicropi, M.S.; Caruso, A.; Pisano, A.; Lappano, R.; Maggiolini, M.; Longo, P. Synthesis, characterization and cytotoxic activity on breast cancer cells of new half-titanocene derivatives. Bioorganic Med. Chem. Lett. 2013, 23, 3458-3462. [CrossRef] [PubMed]

71. Saturnino, C.; Sirignano, E.; Botta, A.; Sinicropi, M.S.; Caruso, A.; Pisano, A.; Lappano, R.; Maggiolini, M.; Longo, P. New titanocene derivatives with high antiproliferative activity against breast cancer cells. Bioorganic Med. Chem. Lett. 2014, 24, 136-140. [CrossRef]

72. Iacopetta, D.; Mariconda, A.; Saturnino, C.; Caruso, A.; Palma, G.; Ceramella, J.; Muià, N.; Perri, M.; Sinicropi, M.S.; Caroleo, M.C.; et al. Novel Gold and Silver Carbene Complexes Exert Antitumor Effects Triggering the Reactive Oxygen Species Dependent Intrinsic Apoptotic Pathway. ChemMedChem 2017, 12, 2054-2065. [CrossRef]

73. Iacopetta, D.; Rosano, C.; Sirignano, M.; Mariconda, A.; Ceramella, J.; Ponassi, M.; Saturnino, C.; Sinicropi, M.S.; Longo, P. Is the Way to Fight Cancer Paved with Gold? Metal-Based Carbene Complexes with Multiple and Fascinating Biological Features. Pharmaceuticals 2020, 13, 91. [CrossRef]

74. Talib, J.; Beck, J.L.; Ralph, S.F. A mass spectrometric investigation of the binding of gold antiarthritic agents and the metabolite [Au(CN)2]- to human serum albumin. JBIC J. Biol. Inorg. Chem. 2006, 11, 559-570. [CrossRef] [PubMed]

75. Özdemir, I.; Denizci, A.; Ozturk, H.T.; Çetinkaya, B. Synthetic and antimicrobial studies on new gold(I) complexes of imidazolidin2-ylidenes. Appl. Organomet. Chem. 2004, 18, 318-322. [CrossRef]

76. Yan, J.J.; Chow, A.L.-F.; Leung, C.-H.; Sun, R.W.-Y.; Ma, D.-L.; Che, C.-M. Cyclometalated gold(iii) complexes with N-heterocyclic carbene ligands as topoisomerase I poisons. Chem. Commun. 2010, 46, 3893-3895. [CrossRef] [PubMed]

77. Champness, N.R. The future of metal-organic frameworks. Dalton Trans. 2011, 40, 10311-10315. [CrossRef]

78. Ward, J.R. Role of disease-modifying antirheumatic drugs versus cytotoxic agents in the therapy of rheumatoid arthritis. Am. J. Med. 1988, 85, 39-44. [CrossRef]

79. Fries, J.F.; Bloch, D.; Spitz, P.; Mitchell, D.M. Cancer in rheumatoid arthritis: A prospective long-term study of mortality. Am. J. Med. 1985, 78, 56-59. [CrossRef]

80. Simon, T.M.; Kunishima, D.H.; Vibert, G.J.; Lorber, A. Inhibitory effects of a new oral gold compound on hela cells. Cancer 1979, 44, 1965-1975. [CrossRef]

81. Simon, T.M.; Kunishima, D.H.; Vibert, G.J.; Lorber, A. Screening trial with the coordinated gold compound auranofin using mouse lymphocyte leukemia P388. Cancer Res. 1981, 41, 94-97. [PubMed]

82. Mirabelli, C.K.; Jensen, B.D.; Mattern, M.R.; Sung, C.M.; Mong, S.M.; Hill, D.T.; Dean, S.W.; Schein, P.S.; Johnson, R.K.; Crooke, S.T. Cellular pharmacology of mu-[1,2-bis(diphenylphosphino)ethane]bis[(1-thio-beta-D-gluco pyranosato-S)gold(I)]: A novel antitumor agent. Anti-Cancer Drug Des. 1986, 1, 223-234. 